\title{
Quantifying the roles of competing static gears: comparative selectivity of longlines and monofilament gill nets in a multi-species fishery of the Algarve (southern Portugal)*
}

\author{
KARIM ERZINI ${ }^{1}$, JORGE M.S. GONÇALVES ${ }^{1}$, LUÍS BENTES ${ }^{1}$, PEDRO G. LINO ${ }^{1}$, \\ JOAQUIM RIBEIRO ${ }^{1}$ and KONSTANTINOS I. STERGIOU ${ }^{2}$ \\ ${ }^{1}$ CCMAR, Universidade do Algarve, 8000-117 Faro, Portugal. E-mail: kerzini@ ualg.pt \\ 2 Department of Ichthyology, Aristotle University of Thessaloniki, Department of Biology, Section of Zoology, \\ Laboratory of Ichthyology, Thessaloniki, Greece.
}

\begin{abstract}
SUMMARY: Fishing trials with monofilament gill nets and longlines using small hooks were carried out in Algarve waters (southern Portugal) over a one-year period. Four hook sizes of "Mustad" brand, round bent, flatted sea hooks (Quality 2316 DT, numbers 15, 13, 12 and 11) and four mesh sizes of 25,30,35 and $40 \mathrm{~mm}$ (bar length) monofilament gill nets were used. Commercially valuable sea breams dominated the longline catches while small pelagics were relatively more important in the gill nets. Significant differences in the catch size frequency distributions of the two gears were found for all the most important species caught by both gears (Boops boops, Diplodus bellottii, Diplodus vulgaris, Pagellus acarne, Pagellus erythrinus, Spondyliosoma cantharus, Scomber japonicus and Scorpaena notata), with longlines catching larger fish and a wider size range than nets. Whereas longline catch size frequency distributions for most species for the different hook sizes were generally highly overlapped, suggesting little or no differences in size selectivity, gill net catch size frequency distributions clearly showed size selection. A variety of models were fitted to the gill net and hook data using the SELECT method, while the parameters of the logistic model were estimated by maximum likelihood for the longline data. The binormal model gave the best fits for most of the species caught with gill nets, while the logistic model adequately described hook selectivity. The results of this study show that the two static gears compete for many of the same species and have different impacts in terms of catch composition and size selectivity. This information will be useful for the improved management of these small-scale fisheries in which many different gears compete for scarce resources.
\end{abstract}

Key words: gill nets, hook, longlines, artisanal, multi-species, selectivity, Portugal, Algarve.

RESUMEN: CUANTIFICANDO EL PAPEL DE ARTES ESTÁTICOS EN COMPETENCIA: SELECTIVIDAD COMPARADA DE PALANGRES Y

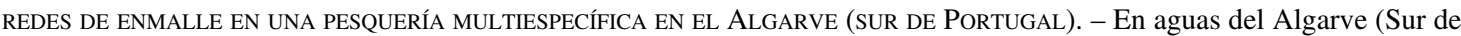
Portugal) durante un año se han llevado a cabo pescas experimentales con redes de enmalle monofilamento y palangres con anzuelos pequeños. Se utilizaron cuatro tamaños (Calidad 2316DT, números 15, 13, 12 y 11) de anzuelos curvados y aplanados, de la marca: "Mustad", y redes de enmalle monofilamento de cuatro tamaños de luz de malla 25, 30, 35 y 40 mm. Por su valor comercial, los espáridos son las especies más importantes de las capturadas por los palangres mientras que los pequeños pelágicos son los de mayor importancia relativa de las capturadas por las redes de enmalle. Se han encontrado diferencias significativas entre los dos tipos de artes en las distribuciones de frecuencias de tallas para todas las especies más importantes capturadas por ambas artes (Boops boops, Diplodus bellottii, Diplodus vulgaris, Pagellus acarne, Pagellus erythrinus, Spondyliosoma cantharus, Scomber japonicus y Scorpaena notata). Con los palangres se capturaron ejemplares de mayor tamaño y en un rango más amplio que con las redes. Mientras que las distribuciones de frecuencias de tallas de las capturas de los diferentes tamaños de anzuelos se solapan en la mayoría de las especies, sugiriendo que no hay diferencias en la selectividad por tamaño o son muy pequeñas, las distribuciones de frecuencias de tallas de las redes de enmalle muestran claramente selección por tamaño. Los datos obtenidos, tanto con las redes de enmalle como con los anzuelos, se 
han ajustado a varios modelos utilizando el método SELECT, mientras que los parámetros del modelo logístico de los palangres se estimaron mediante el método de máxima verosimilitud. El modelo bi-modal proporciona el mejor ajuste para la mayoría de las especies capturadas con las redes de enmalle, mientras que el modelo logístico es el más adecuado para describir la selectividad de los anzuelos. Los resultados de este estudio muestran que ambas artes pasivas compiten por muchas de las mismas especies y tienen diferentes impactos en cuanto a la composición y tamaño de captura. Esta información puede ser útil para mejorar el manejo de estas pesquerías a pequeña escala donde distintos tipos de artes compiten por los escasos recursos.

Palabras claves: red de enmalle, anzuelo, palangre, artesanal, multiespecífica, selectividad, Portugal, Algarve.

\section{INTRODUCTION}

Small-scale fisheries involving large numbers of small fishing vessels and a variety of fishing gears are of great socio-economic importance in Portugal. Gill nets, trammel nets and longlines are the most widely used and important gears in these fisheries. In the Algarve (southern Portugal), 871, 611 and 506 out of a total of 3343 licences issued in 2002 to 1241 fishing vessels were for longlines, trammel nets and gill nets respectively (pers. com., DGPA).

Despite the major socio-economic importance of small-scale fisheries, many aspects have not been comprehensively studied. Thus, there are few thorough studies dealing with the major features of the artisanal fisheries in the Algarve (gill net species composition: Martins et al., 1992; catch rates: Martins et al., 1992; gill net selectivity: Santos and Monteiro, 1995; Santos, 1997; Santos et al., 1995, 1998; longline species composition, catch rates and selectivity: Erzini et al., 1996a, b, 1998; ghost fishing: Erzini et al., 1997a).

It has long been recognised that the analysis of factors causing variation in the degree of vulnerability of different species and size groups to various types of gear is important for the development of optimal harvesting strategies and the rational use of living resources (Clark, 1960). The problem of gear competition is particularly important from the socioeconomic point of view, especially so for artisanal fishers (Durand et al., 1991; Anon., 1995). While a number of studies have compared two or more gears in terms of catch composition, catch rates and size selectivity (Rollefsen, 1953; Russell et al., 1988; Elliott and Beamesderfer, 1990; Engas et al., 1993; Nedreaas et al., 1993; Hareide, 1995; Jorgensen, 1995; Huse et al., 1999), very few studies have been based on the comparison of gear fished commercially and simultaneously on the same fishing grounds (Huse et al., 2000; Stergiou and Erzini, 2002).

The present study compared the size selectivity of two competing fixed or static gears: gill nets and longlines in southern Portuguese waters. The study involved simultaneous fishing trials using two commercial vessels fishing on the same fishing grounds with gill nets of four mesh sizes and longlines of four hook sizes. In this paper we present the results of the comparison of the two gears in terms of size selectivity. Selectivity parameters for the species caught in sufficient numbers by both gears were estimated and the selectivity curves were compared. These coastal fisheries resources are largely managed on the basis of licenses and technical measures such as minimal landing sizes and minimum mesh sizes. Thus, the information obtained will contribute to the more rational management of these overfished resources.

\section{MATERIALS AND METHODS}

Experimental fishing with two chartered commercial small-scale fishing vessels was conducted in the Algarve, southern Portugal (Fig. 1) in 1997-1998 using gill nets and longlines. Sampling depths ranged from 15 to $60 \mathrm{~m}$ and fishing started in July 1997 and ended in June 1998. Overall, 40 experimental fishing trials were conducted with gill nets and 40 with longlines.

The longlines were constructed by the fishermen contracted for the study in accordance with local gear specifications. Four hook sizes (hook numbers: 15, 13, 12 and 11) of MUSTAD round bend spade end hooks (Quality 2316 DT) were used. The main line was of $1.1 \mathrm{~mm}$ diameter mono-filament and the gangions were of $0.5 \mathrm{~mm}$ monofilament, $80 \mathrm{~cm}$ in length and spaced approximately $1.7 \mathrm{~m}$ apart (Erzini et al., 1996a, 1998). The dimensions of the hooks used are given in Fig. 2. Gill nets of 25, 30, 35 and $40 \mathrm{~mm}$ nominal bar length were of $0.30 \mathrm{~mm}$ green monofilament, 40 meshes deep, with a hanging ratio in the floatline of 0.5 .

Five longline tubs were used, each containing a longline with four 100 hook sections of the four hook sizes used, for a total of 2000 hooks. The experimental gill nets consisted of approximately 


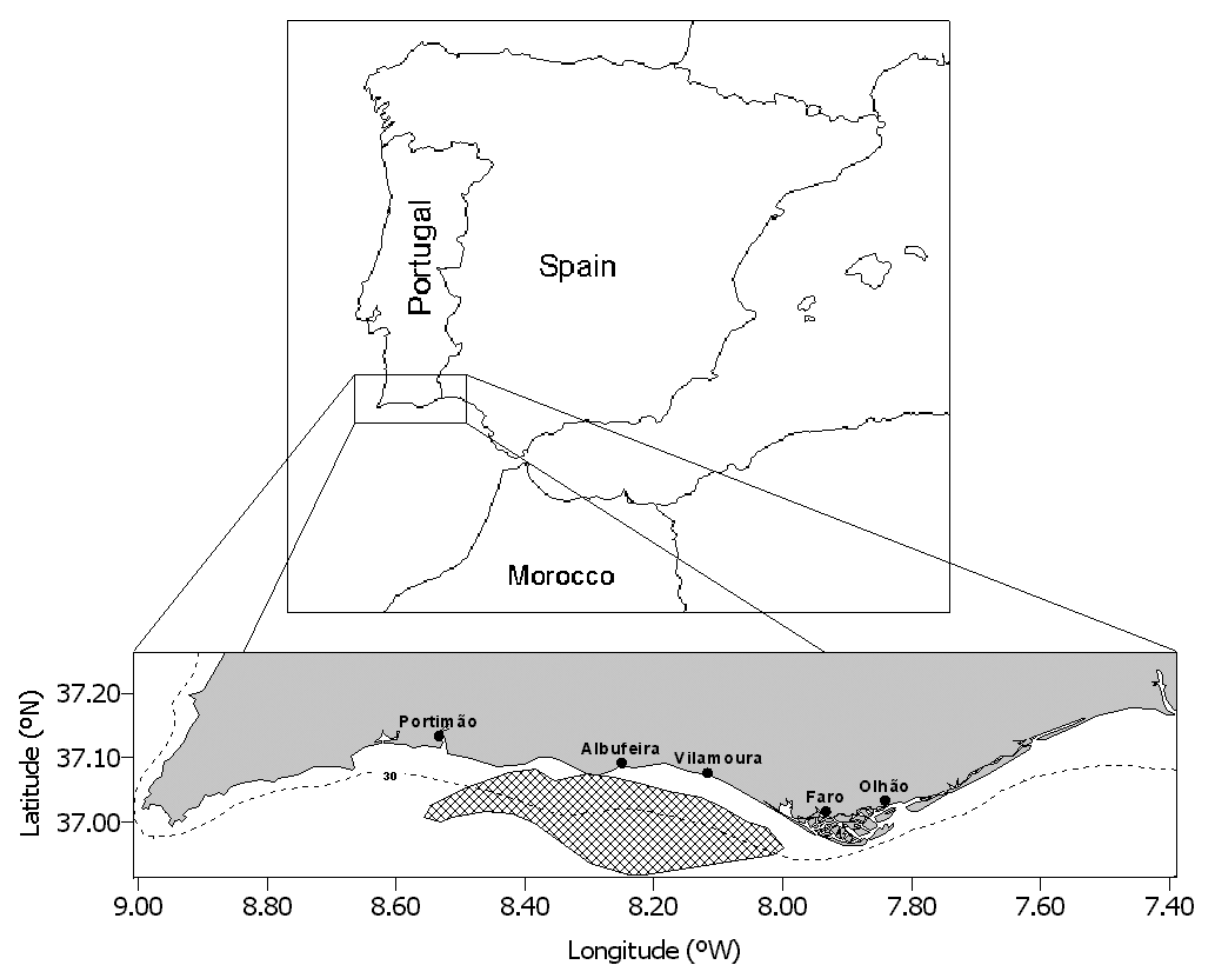

FIG. 1. - Map of the Algarve (southern Portugal) showing the area where the comparative fishing trials took place.

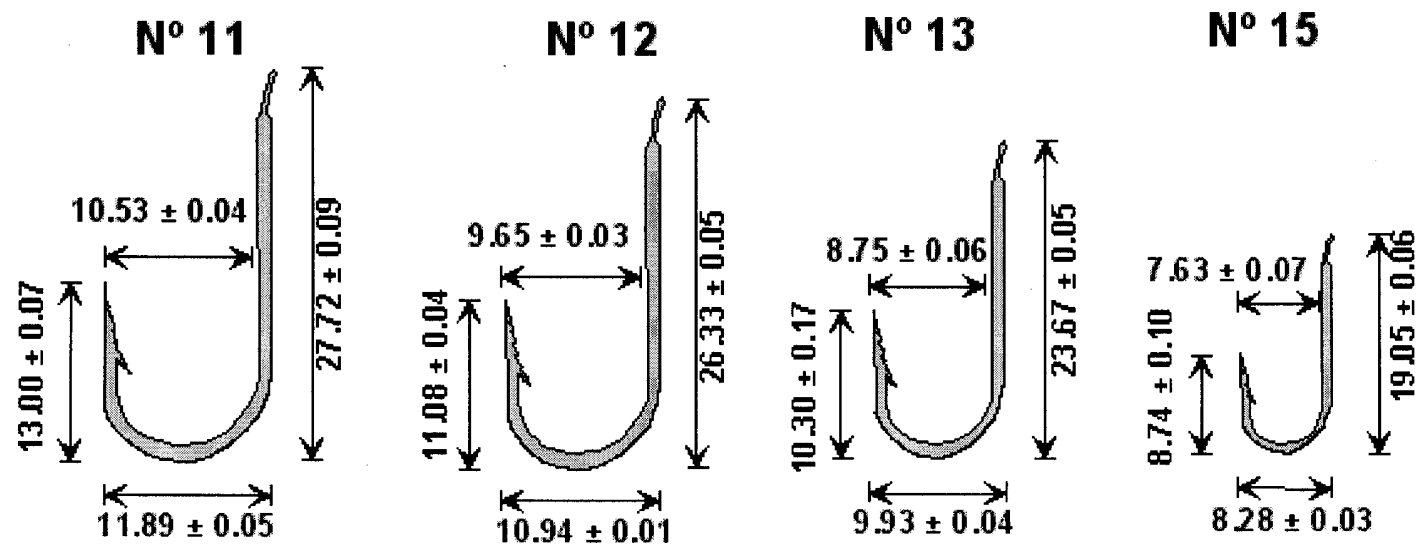

FIG. 2. - Dimensions $(\mathrm{mm}+$ s.e.) of the four hook sizes used in the fishing trials. Vertical measurements from left to right are depth and length, horizontal measurements from top to bottom are gap and width. Maximum size is width $\mathrm{x}$ length.

$250 \mathrm{~m}$ sections of each mesh size in a random sequence, with each section separated by a $20 \mathrm{~m}$ rope. A total of $750 \mathrm{~m}$ of netting of each mesh size was used.

The fishing grounds were selected by the fishermen in traditional fishing areas in order to ensure the highest possible catches of the most commercially important species targeted by the local gill net and long-line fisheries. Normal fishing practices were followed, with the gears fished simultaneously one to two hours either before sunrise or sunset and retrieved one to two hours after sunrise or sunset respectively. For comparative purposes the two vessels always set their gear in close proximity on the same fishing grounds. Standard sized sipunculid worm (Sipuncula nudus) baits were used to bait the hooks. The worms, which were 15 to $18 \mathrm{~cm}$ in length, were first cut in rings of approximately equal width and each ring was cut open to provide a strip bait. The sipunculid strips were randomly selected when the longlines were baited.

After hauling, the catch was immediately removed and separated by hook and mesh size. The number of specimens and the total weight per 
species were recorded. Individual fish were measured (total length, TL, to the nearest $\mathrm{mm}$ ) and weighed (gross wet weight, $\mathrm{W}$, to the nearest $\mathrm{g}$ ). The pooled catch size frequency distributions for each gear by species were compared with the Kolomogorov-Smirnov test (Siegel and Castellan, 1988).

The SELECT method of Millar (1992), implemented in the GILLNET (CONSTAT, 1998) software was used to estimate the parameters of five gillnet selectivity models. Under the assumption that relative fishing intensities are constant, the general model for analysis of data from comparative fishing trials with gears of different sizes is:

$$
\mathrm{n}_{l j} \approx \operatorname{Pois}\left(\mathrm{p}_{j} \lambda_{l} \mathrm{r}_{j}(l)\right)
$$

The log-likelihood of $\mathrm{n}_{l j}$ is

$$
\sum_{l} \sum_{j}\left\{n_{l} \log _{e}\left[p_{j} \lambda_{l} r_{j}(l)\right]-p_{j} \lambda_{l} r_{j}(l)\right\} .
$$

In this model (Millar and Fryer, 1999) it is assumed that $\mathrm{n}_{l j}$, the number of fish of length $l$ caught in mesh size $j$, has a Poisson distribution. Three processes determine each $\mathrm{n}_{l j}$ : (a) $\lambda_{l}$, the abundance of length $l$ fish contacting the combined gear; (b) $\mathrm{p}_{j}(l)$, the relative fishing intensity, which is the probability that a fish of length $l$ contacts gear $j$, given that it has come into contact with the combined gear. The number of length $l$ fish coming into contact with gear $j$ is also Poisson distributed with mean $\mathrm{p}_{j}(l) \lambda_{l}$ since the number of contacts to the combined gear is Poisson distributed with mean $\lambda_{l}$ (Feller, 1968; cited in Millar and Fryer, 1999); (c) $\mathrm{r}_{j}(l)$ is the contact selection curve for a given gear size $j$.

The number of parameters to be estimated is reduced in the SELECT method because proportions of the total catch for each length class and each gear are used $\left(\mathrm{y}_{l j}=\mathrm{n}_{l j} / \mathrm{n}_{l+}\right.$, where $\mathrm{n}_{l+}$ is the total catch for each length class for all gears), thereby eliminating the $\lambda_{l}$ parameters (abundance) from the maximisation problem. The proportions have a multinomial distribution with $\mathrm{n}_{l+}$ trials and probabilities:

$$
\phi_{l j}=\frac{p_{j} r_{j}(l)}{\sum_{j} p_{j} r_{j}(l)}
$$

where $\mathrm{j}=1$ to $\mathbf{J}$ (for $\mathbf{J}$ mesh sizes). The log-likelihood for the proportions $\left(\mathrm{y}_{l j}\right)$ is:

$$
\sum_{l} \sum_{j} n_{l j} \log _{e}\left(\phi_{l j}\right) \text {. }
$$

The software package GILLNET (CONSTAT, 1998) incorporates a very stable and efficient engine, which uses the first and second derivatives of the log-likelihood function to find its maximum (R. Holst, Denmark, pers. com.). This ensures a relatively quick estimation of its maximum point. Experience indicates that the algorithm is very robust to the starting values. However, a good starting point may significantly reduce the number of iterations required to reach the maximum point.

The parameters of five selection curves were estimated using GILLNET: Normal location, Normal scale. Lognormal, Gamma and Bi-normal. In all models except the Normal location, the spread is proportional to mesh size according to the principle of geometrc similarity (Baranov, 1914). All models were fitted to the species with sufficient data for the estimation of selectivity parameters and the goodness of fit evaluated by comparison of deviancies and examination of the plots of the deviance residuals. The best model is that with the smallest deviance.

Since previous studies on some of the same species had shown that sigmoid hook size selection curves were probably more appropriate than domeshaped curves (Erzini et al., 1998), the logistic model was also fitted to the longline catch for the same nine species. As in other hook selectivity studies (Erzini et al., 1996a,b, 1997b, 1998; Sousa et al., 1999), the Wulff (1986) and Kirkwood and Walker (1986) method was used to estimate the parameters of the logistic selectivity curve for hooks. The NLP procedure in SAS (SAS Institute Inc., 1988; Hartman, no date) was used to maximise the following likelihood:

$$
\sum_{l, m}\left[c_{l, m} \cdot \ln \left(S_{l, m} / \sum_{m} S_{l, m}\right)\right] .
$$

were $c_{l, m}$ and $S_{l, m}$ are the catches and the selectivities for size classes $l$ and hook sizes $m$. This method is based on the principle of geometric similarity (Wulff, 1986) in which the parameters $b$ and $L_{50}$ of the logistic model are a function of hook size. This model is essentially equivalent to that implemented in the GILLNET software, where the parameters of various uni-modal selectivity curves can be modelled in this manner. Thus, the selectivity for hook size $i$ and fish size class $j$ is defined as:

$$
S_{l, m}=\frac{1}{1+e^{-b_{1} H_{j}\left(L_{l}-b_{2} H_{j}\right)}}
$$


TABLE 1. - The 10 most important species in numbers caught by gill nets.

\begin{tabular}{lrrrr}
\hline Species & $\mathrm{n}$ & $\%$ & weight $(\mathrm{kg})$ & $\%$ \\
\hline Scomber japonicus & 3345 & 29.1 & 188.9 & 17.4 \\
Diplodus bellottii & 1376 & 12.0 & 94.8 & 8.7 \\
Scorpaena notata & 963 & 8.4 & 60.3 & 5.5 \\
Trachurus trachurus & 948 & 8.2 & 75.3 & 6.9 \\
Pagellus acarne & 730 & 6.4 & 103.1 & 9.5 \\
Sardina pilchardus & 701 & 6.1 & 44.8 & 4.1 \\
Mullus surmuletus & 579 & 5.0 & 85.3 & 7.8 \\
Diplodus vulgaris & 544 & 4.7 & 65.4 & 6.0 \\
Pagellus erythrinus & 510 & 4.4 & 67.0 & 6.2 \\
Spondyliosoma cantharus & 272 & 2.4 & 37.3 & 3.4 \\
Total & & & & \\
& 9968 & 86.7 & 822.2 & 75.5 \\
\hline
\end{tabular}

where $\mathrm{S}_{j l}$ is the selectivity for hook size $j$ and length class $l, \mathrm{H}_{j}$ is the size of hook $j$, the slope, $b$, is equal to $-\mathrm{b}_{1} \mathrm{H}_{j}$ and $L_{50}=-\mathrm{b}_{2} \mathrm{H}_{j}$. Five different models corresponding to different hook dimensions (gap, width, depth, length and maximum size) were fitted and the goodness of fit was evaluated by comparison of the values of the maximum likelihood.

\section{RESULTS}

The ten most important species in numbers caught by gill nets and longlines in the fishing trials are given in Tables 1 and 2. As can be seen, 6 of the top ten species were common to both gears and of these 5 were sea breams (Sparidae). Three of the most important gill net species were pelagics
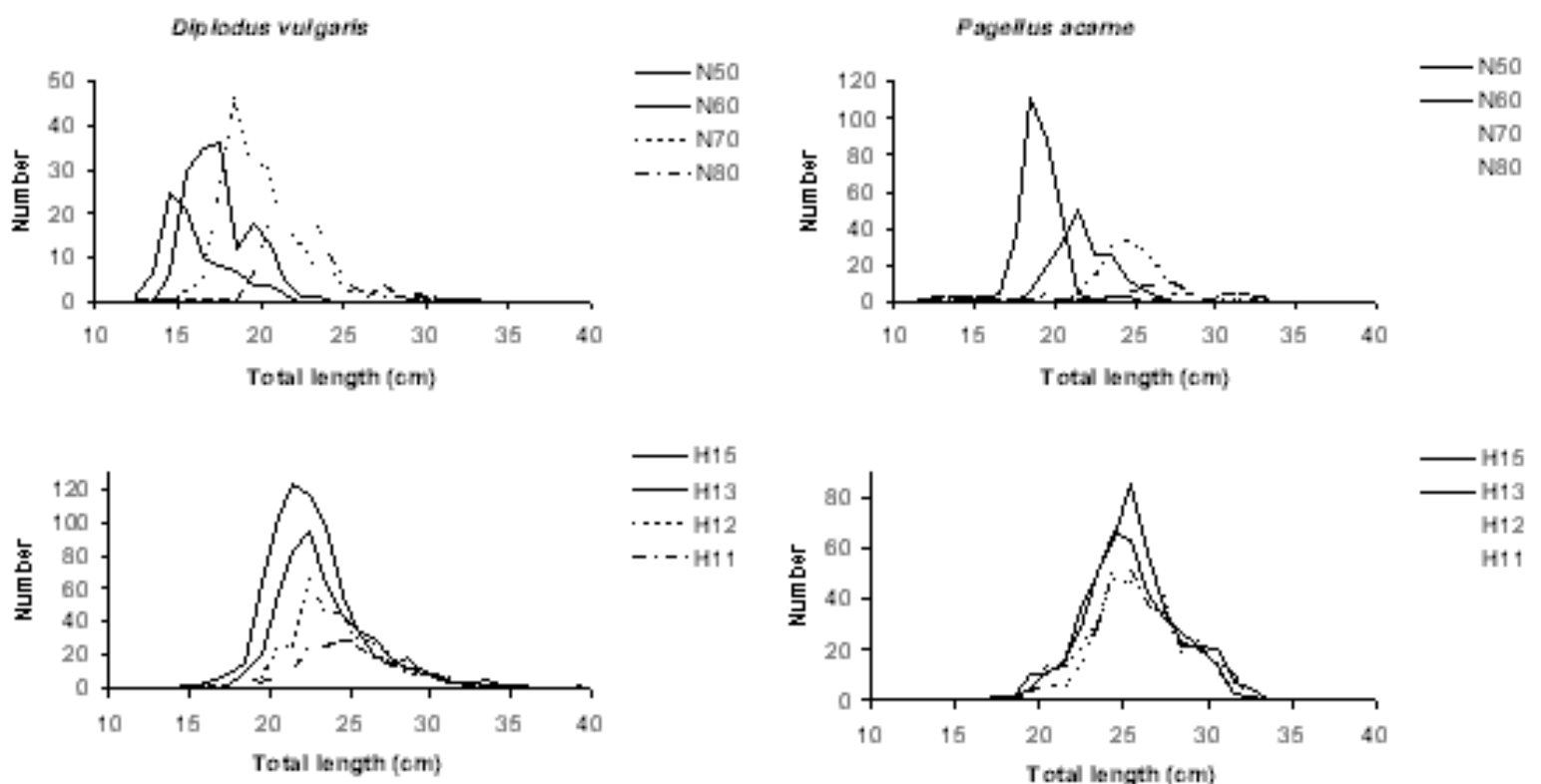

TABLE 2. - The 10 most important species in numbers caught by longline.

\begin{tabular}{lrrrr}
\hline Species & $\mathrm{n}$ & $\%$ & weight $(\mathrm{kg})$ & $\%$ \\
\hline Diplodus vulgaris & 1754 & 23.2 & 385.6 & 23.8 \\
Pagellus acarne & 1463 & 19.4 & 345.1 & 21.3 \\
Spondyliosoma cantharus & 1025 & 13.6 & 207.4 & 12.8 \\
Diplodus bellottii & 558 & 7.4 & 49.1 & 3.0 \\
Scorpaena notata & 454 & 6.0 & 25.1 & 1.6 \\
Boops boops & 400 & 5.3 & 32.8 & 2.0 \\
Pagellus erythrinus & 388 & 5.1 & 163.1 & 10.0 \\
Diplodus sargus & 368 & 4.9 & 182.8 & 11.3 \\
Conger conger & 309 & 4.1 & 78.3 & 4.8 \\
Serranus cabrilla & 170 & 2.3 & 15.9 & 1.0 \\
& & & & \\
Total & 6889 & 91.1 & 1485.2 & 91.5 \\
& & & & \\
\hline
\end{tabular}

(Scomber japonicus, Trachurus trachurus and Sardina pilchardus) that were caught in reduced numbers or in the case of the sardine not at all by longline.

Of the most important species caught by both gears, catches of Diplodus vulgaris, Pagellus acarne and Spondyliosoma cantharus were greater with longlines, while gill nets accounted for more Diplodus bellotti, Pagellus erythrinus, and Scorpaena notata. It is interesting to note that Mullus surmuletus and Diplodus sargus were caught exclusively by gill nets and longlines respectively.

The length frequency distributions of the four most important commercial species caught by both gears (Diplodus vulgaris, Pagellus acarne, Pagellus erythrinus and Spondyliosoma cantharus) are shown in Figures 3 and 4. In general longlines caught a wide size range with larger specimens of the same



FIG. 3. - Catch size frequency distributions for four sizes of monofilament gill net and four hook sizes for Diplodus vulgaris and Pagellus acarne. 



FIG. 4. - Catch size frequency distributions for four sizes of monofilament gill net and four hook sizes for Pagellus erythrinus and Spondyliosoma cantharus.

TABLE 3. - Results of the Kolmogorov-Smirnov test used to compare longline and gill net catch size frequency distributions. Critical values are from Siegal and Castellan (1988).

\begin{tabular}{|c|c|c|c|c|}
\hline \multirow{2}{*}{$\begin{array}{l}\text { Species } \\
\text { Boops boops }\end{array}$} & \multirow{2}{*}{$\begin{array}{c}\begin{array}{c}\text { Longline } \\
\mathrm{m}\end{array} \\
381\end{array}$} & \multirow{2}{*}{$\begin{array}{c}\begin{array}{c}\text { Gill net } \\
n\end{array} \\
164\end{array}$} & \multicolumn{2}{|c|}{$\begin{array}{l}\text { Critical values } \\
\text { of } \mathrm{Dm}, \mathrm{n} \\
\operatorname{Dmax}(\mathrm{p}=0.05)\end{array}$} \\
\hline & & & 0.47 & 0.127 \\
\hline Diplodus bellottii & 541 & 1331 & 0.38 & 0.069 \\
\hline Diplodus vulgaris & 1736 & 532 & 0.56 & 0.067 \\
\hline Pagellus acarne & 1452 & 702 & 0.53 & 0.063 \\
\hline Pagellus erythrinus & 386 & 489 & 0.74 & 0.093 \\
\hline Spondyliosoma cantharus & 1021 & 268 & 0.38 & 0.093 \\
\hline Scomber japonicus & 161 & 2335 & 0.27 & 0.111 \\
\hline Scorpaena notata & 447 & 955 & 0.13 & 0.078 \\
\hline
\end{tabular}

species than gill nets (e.g. Figs. 3 and 4). A decrease in catch rate with increasing hook size and highly overlapped catch size frequency distributions were also characteristic (Figs. 3 and 4). In contrast, all four gill net mesh sizes caught relatively narrow length ranges and the modal lengths of the species caught gradually increased with increasing mesh size (Figs. 3 and 4). The pooled catch size frequency distributions of gill nets and longlines were significantly different for the 8 most important species caught by both gears (Table 3 ).

Gill net and hook selectivity parameters were estimated for the four species caught by both gears that were most important in terms of numbers and commercial value: Diplodus vulgaris, Pagellus acarne, Pagellus erythrinus and Spondyliosoma cantharus. The parameters of the different models fitted as well as the deviance, which is the likelihood ratio goodness of fit statistic, and the corresponding degrees of freedom for the best unimodal and the binormal model are presented in Table 4 . The binormal model provided by far the best fits for three out of the four species, while the normal spread model was best for Pagellus acarne. In general, the

TABLE 4. - Best unimodel and binormal model SELECT fits for the gill net data.

\begin{tabular}{|c|c|c|c|c|c|}
\hline Species & Model & Spread & Parameters & Model deviance & df \\
\hline Diplodus vulgaris & $\begin{array}{l}\text { Lognormal: } \\
\text { Binormal: }\end{array}$ & $\begin{array}{l}\alpha \mathrm{m}_{\mathrm{j}} \\
\alpha \mathrm{m}_{\mathrm{j}}\end{array}$ & $\begin{array}{c}\left(\mu_{1}, \sigma\right)=(2.7114,0.1339) \\
\left(\mathrm{k}_{1}, \mathrm{k}_{2}, \mathrm{k}_{3}, \mathrm{k}_{4}, \mathrm{c}\right)=(0.555,0.0353,0.665,0.097,0.444)\end{array}$ & $\begin{array}{r}136.39 \\
78.92\end{array}$ & $\begin{array}{l}58 \\
55\end{array}$ \\
\hline Pagellus acarne & $\begin{array}{l}\text { Normal: } \\
\text { Binormal: }\end{array}$ & $\begin{array}{l}\alpha \mathrm{m}_{\mathrm{j}} \\
\alpha \mathrm{m}_{\mathrm{j}}\end{array}$ & $\begin{aligned}\left(\mathrm{k}_{1}, \mathrm{k}_{2}\right)= & (0.7703,0.0910) \\
& \text { no fit }\end{aligned}$ & 358.07 & 67 \\
\hline Pagellus erythrinus & $\begin{array}{l}\text { Gamma: } \\
\text { Binormal: }\end{array}$ & $\alpha \mathrm{m}_{\mathrm{j}}$ & $\begin{array}{c}(\mathrm{a}, \mathrm{k})=(76.2174,0.0097) \\
\left(\mathrm{k}_{1}, \mathrm{k}_{2}, \mathrm{k}_{3}, \mathrm{k}_{4}, \mathrm{c}\right)=(0.689,0.0424,0.806,0.108,0.458)\end{array}$ & $\begin{array}{r}132.96 \\
73.24\end{array}$ & $\begin{array}{l}67 \\
64\end{array}$ \\
\hline Spondyliosoma cantharus & $\begin{array}{l}\text { Lognormal: } \\
\text { Binormal: }\end{array}$ & $\begin{array}{l}\alpha \mathrm{m}_{\mathrm{j}} \\
\alpha \mathrm{m}_{\mathrm{j}}\end{array}$ & $\begin{array}{c}\left(\mu_{1}, \sigma\right)=(2.8303,0.1343) \\
\left(\mathrm{k}_{1}, \mathrm{k}_{2}, \mathrm{k}_{3}, \mathrm{k}_{4}, \mathrm{c}\right)=(0.631,0.0435,0.757,0.122,0.385)\end{array}$ & $\begin{array}{l}79.15 \\
48.27\end{array}$ & $\begin{array}{l}52 \\
49\end{array}$ \\
\hline
\end{tabular}


a
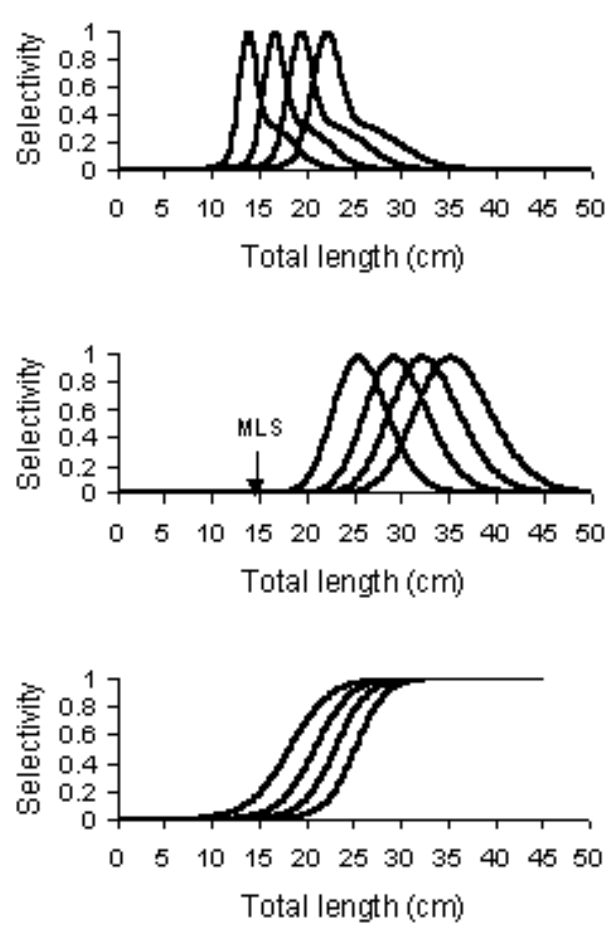

C
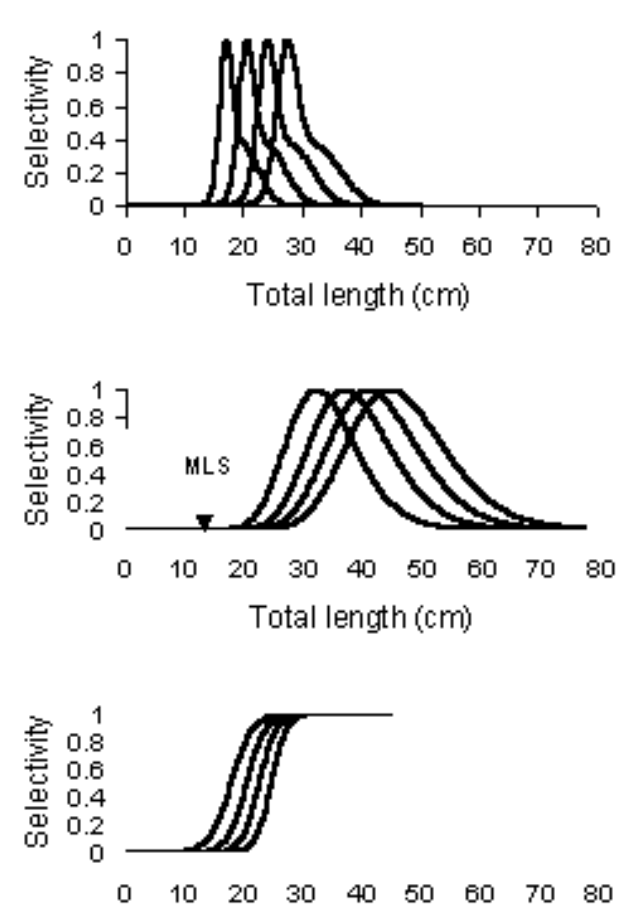

b
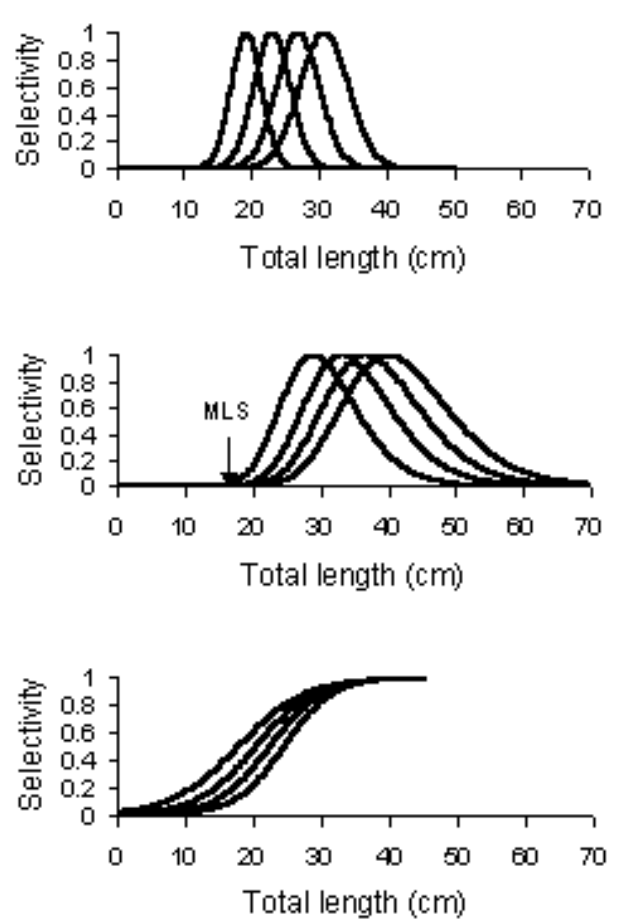

d
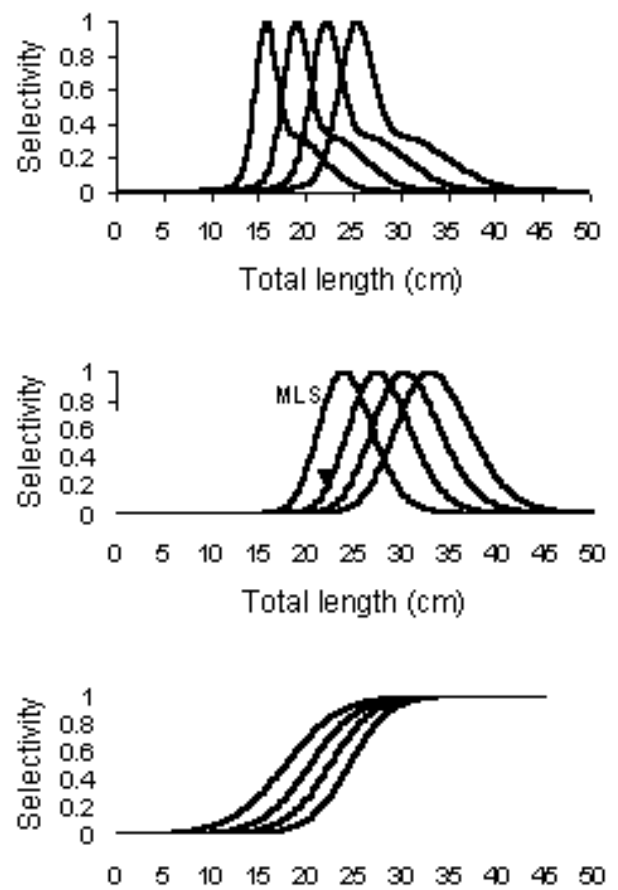

FIG. 5. - Gill net and longline selectivity curves for the four most important species caught by both gears. For each species: top, best gill net selectivity; middle, best uni-modal model hook selectivity; and bottom, logistic hook selectivity. MLS is the minimum landing size.

deviances of the best models were in all cases equal or marginally better under the assumption of fishing power proportional to mesh size, and the deviance residuals were also generally similar under both assumptions. The probabilities of capture for the four mesh sizes for Diplodus vulgaris, Pagellus acarne, Pagellus erythrinus and Spondyliosoma cantharus are shown in Figure 5 and the corre- 

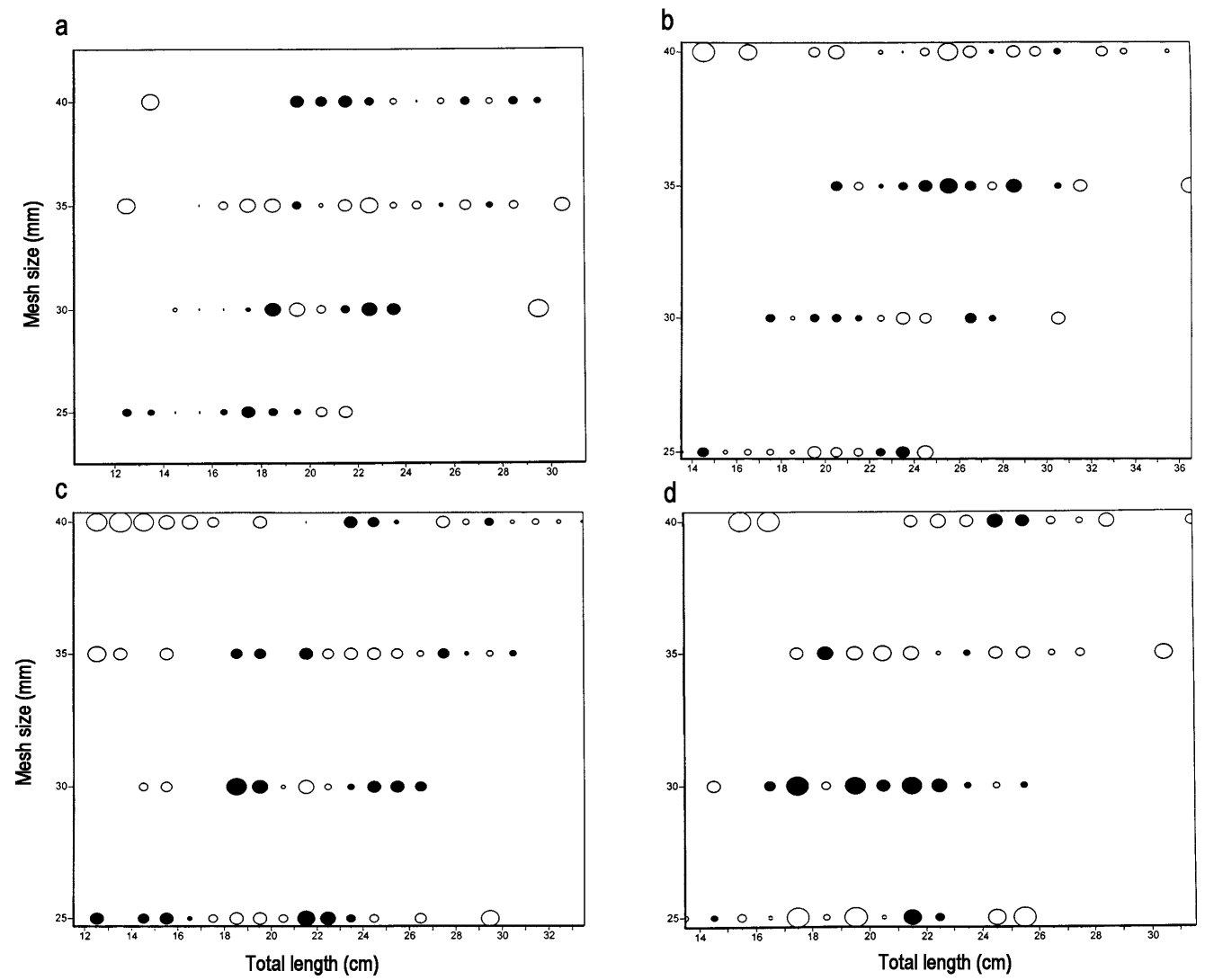

FIG. 6. - Deviance residual plots for the gill net selection fits shown in Figure 5. Open and filled circles are positive and negative residuals respectively. The area of the circle is proportional to the absolute value of the residual.

sponding deviance residuals are shown in Figure 6.

The modal lengths and corresponding spread of the most important species for the four mesh sizes for the best unimodal model are shown in Table 5. The modal lengths increased with mesh size, from 14.8 to $23.7 \mathrm{~cm}$ for Diplodus vulgaris, from 19.3 to $30.8 \mathrm{~cm}$ for Pagellus acarne, from 18.3 to $29.2 \mathrm{~cm}$ for Pagellus erythrinus and from 16.7 to $26.6 \mathrm{~cm}$ for Spondyliosoma cantharus. The spread also increased with mesh size in all cases.

SELECT model fits under the assumption of equal fishing powers for fish caught with longlines are given in Table 6 . The lognormal model was best for Diplodus vulgaris and Pagellus erythrinus while

TABLE 5. - Modal length and spread for the best unimodal gill net selectivity curves for the species in Table 4.

\begin{tabular}{|c|c|c|c|c|c|c|c|c|c|}
\hline \multirow[t]{2}{*}{ Species } & \multirow[t]{2}{*}{ Model } & \multicolumn{8}{|c|}{ Gill net mesh size } \\
\hline & & $\begin{array}{r}50 \mathrm{~mm} \\
\text { Modal length }\end{array}$ & Spread & $\begin{array}{r}60 \mathrm{~mm} \\
\text { Modal lengtl }\end{array}$ & pread & $\begin{array}{r}70 \mathrm{~mm} \\
\text { Modal length }\end{array}$ & Spread & $\begin{array}{r}80 \mathrm{~mm} \\
\text { Modal length }\end{array}$ & Spread \\
\hline Diplodus vulgaris & Lognormal & 14.78 & 2.04 & 17.74 & 2.45 & 20.70 & 2.86 & 23.65 & 3.27 \\
\hline Pagellus acarne & Normal scale & 19.26 & 2.28 & 23.11 & 2.73 & 26.96 & 3.19 & 30.81 & 3.64 \\
\hline Pagellus erythrinus & Gamma & 18.27 & 2.11 & 21.92 & 2.53 & 25.58 & 2.95 & 29.23 & 3.37 \\
\hline Spondyliosoma cantharus & Lognormal & 16.65 & 2.31 & 19.98 & 2.77 & 23.31 & 3.23 & 26.64 & 3.69 \\
\hline
\end{tabular}

TABLE 6. - Best unimodel SELECT fits for longline data.

\begin{tabular}{|c|c|c|c|c|c|}
\hline Species & Model & Spread & Parameters & Model deviance & df \\
\hline D. vulgaris & Lognormal & $\alpha \mathrm{m}_{\mathrm{i}}$ & $\left(\mu_{1}, \sigma\right)=(3.2500,0.2253)$ & 96.91 & 70 \\
\hline P. acarne & Gamma & $\alpha \mathrm{m}_{\mathrm{j}}$ & $(\alpha, k)=(8.9489,4.2597)$ & 51.49 & 58 \\
\hline P. erythrinus & Lognormal & $\alpha \mathrm{m}_{\mathrm{j}}$ & $\left(\mu_{1}, \sigma\right)=(3.5065,0.3601)$ & 106.70 & 94 \\
\hline S. cantharus & Normal & Fixed & $(\mathrm{k}, \sigma)=(29.8145,6.0300)$ & 65.92 & 76 \\
\hline
\end{tabular}


TABLE 7. - Modal length $(\mathrm{cm})$ and spread for best unimodal longline selectivity curves.

\begin{tabular}{|c|c|c|c|c|c|c|c|c|}
\hline \multirow[t]{3}{*}{ Species } & \multicolumn{8}{|c|}{ Hook size } \\
\hline & \multicolumn{2}{|c|}{ No. 15} & \multicolumn{2}{|c|}{ No. 13} & \multicolumn{2}{|c|}{ No. 12} & \multirow{2}{*}{\multicolumn{2}{|c|}{$\begin{array}{l}\text { No. } 11 \\
\text { M }\end{array}$}} \\
\hline & Modal length & Spread & Modal length & Spread & Modal length & Spread & & \\
\hline Diplodus vulgaris & 24.51 & 6.04 & 28.11 & 6.92 & 31.00 & 7.63 & 33.83 & 8.32 \\
\hline Pagellus acarne & 25.97 & 12.99 & 29.78 & 14.90 & 32.85 & 16.43 & 35.84 & 17.92 \\
\hline Pagellus erythrinus & 29.27 & 13.23 & 33.57 & 15.18 & 37.03 & 16.74 & 40.40 & 18.26 \\
\hline Spondyliosoma cantharus & 24.21 & 4.64 & 27.76 & 5.32 & 30.61 & 5.87 & 33.41 & 6.40 \\
\hline
\end{tabular}

the Gamma model and the normal with fixed spread were best for Pagellus acarne and Spondyliosoma cantharus respectively. The fitted selectivity curves are given in Figure 5 and can be compared with those for fish caught with gill nets.

The modal lengths and spreads corresponding to the best fits for the four most important species caught by longline are given in Table 7. Compared to the modal lengths of the same species caught by gill net (Table 5), longline modal lengths were generally greater, with significantly greater spreads, indicating that the longlines catch a wider size range and generally larger fish than gill nets. For example, the modal length for Diplodus vulgaris caught with the smallest hook (No. 15) is larger than that of the largest gill net mesh size and the spread was approximately twice that of the $80 \mathrm{~mm}$ mesh size gill net.

The results of the non-linear maximisation are given in Table 8, and the calculated parameters of the logistic curve for each fitting and hook size are presented in Table 9. Although fits for two hook dimensions were not possible for Pagellus erythri$n u s$, for the remaining species the hook dimension depth gave the worst fits in all cases, with hook gap and width generally providing the best fits for all species. The fitted logistic selectivity curves

TABLE 8. - Parameter estimates for logistic model hook selectivity where the parameters $\left(\mathrm{b}\right.$ and $\left.\mathrm{L}_{50}\right)$ are a function of hook dimension $(\mathrm{b}=$ b1 x hook dimension, $\mathrm{L}_{50}=\mathrm{b} 2 \mathrm{x}$ hook dimension).

\begin{tabular}{|c|c|c|c|c|c|c|}
\hline Species & Hook dimension & b1 & s.e. & b2 & s.e & Maximum likelihood \\
\hline Diplodus vulgaris & $\begin{array}{l}\text { Gap } \\
\text { Width } \\
\text { Depth (crook) } \\
\text { Length } \\
\text { Maximum size }\end{array}$ & $\begin{array}{l}0.6089 \\
0.5263 \\
0.3979 \\
0.2277 \\
0.1425\end{array}$ & $\begin{array}{l}0.0491 \\
0.0447 \\
0.0500 \\
0.0232 \\
0.0160\end{array}$ & $\begin{array}{r}23.8698 \\
21.0787 \\
20.0931 \\
8.8740 \\
7.8929\end{array}$ & $\begin{array}{l}0.3521 \\
0.2926 \\
0.6075 \\
0.1164 \\
0.2290\end{array}$ & $\begin{array}{l}-2155.84 \\
-2154.83 \\
-2180.47 \\
-2155.83 \\
-2169.74\end{array}$ \\
\hline Pagellus acarne & $\begin{array}{l}\text { Gap } \\
\text { Width } \\
\text { Depth (crook) } \\
\text { Length } \\
\text { Maximum size }\end{array}$ & $\begin{array}{l}0.2658 \\
0.2292 \\
0.2165 \\
0.0944 \\
0.0711\end{array}$ & $\begin{array}{l}0.0750 \\
0.0674 \\
0.0649 \\
0.0284 \\
0.0293\end{array}$ & $\begin{array}{r}23.1613 \\
20.4474 \\
18.3525 \\
8.7477 \\
7.3346\end{array}$ & $\begin{array}{l}1.0731 \\
0.9784 \\
0.7847 \\
0.4350 \\
0.4343\end{array}$ & $\begin{array}{l}-1992.77 \\
-1992.81 \\
-1995.27 \\
-1992.59 \\
-1993.24\end{array}$ \\
\hline Pagellus erythrinus & $\begin{array}{l}\text { Gap } \\
\text { Width } \\
\text { Length }\end{array}$ & $\begin{array}{l}0.7267 \\
0.6142 \\
0.2188\end{array}$ & $\begin{array}{l}0.2451 \\
0.2169 \\
0.1050\end{array}$ & $\begin{array}{r}23.4531 \\
20.7816 \\
8.8818\end{array}$ & $\begin{array}{r}0.7084 \\
0.6747 \\
0.4884\end{array}$ & $\begin{array}{l}-524.58 \\
-524.46 \\
-525.45\end{array}$ \\
\hline Spondyliosoma cantharus & $\begin{array}{l}\text { Gap } \\
\text { Width } \\
\text { Depth (crook) } \\
\text { Length } \\
\text { Maximum size }\end{array}$ & $\begin{array}{l}0.4518 \\
0.3975 \\
0.3125 \\
0.1721 \\
0.1152\end{array}$ & $\begin{array}{l}0.0627 \\
0.0558 \\
0.0456 \\
0.0260 \\
0.0174\end{array}$ & $\begin{array}{r}23.1161 \\
20.3679 \\
19.1586 \\
8.5846 \\
7.4777\end{array}$ & $\begin{array}{l}0.4986 \\
0.4161 \\
0.5677 \\
0.1694 \\
0.1951\end{array}$ & $\begin{array}{l}-1354.84 \\
-1354.75 \\
-1358.87 \\
-1356.67 \\
-1356.86\end{array}$ \\
\hline
\end{tabular}

TABLE 9. - Parameters of the logistic model fitted to longline data. Both $b$ and $\mathrm{L}_{50}$ are a function of hook size (gap).

\begin{tabular}{|c|c|c|c|c|c|c|c|c|}
\hline \multirow[b]{3}{*}{ Species } & \multirow{2}{*}{\multicolumn{2}{|c|}{15}} & \multicolumn{4}{|c|}{ Hook number } & \multirow{2}{*}{\multicolumn{2}{|c|}{11}} \\
\hline & & & & & & & & \\
\hline & $\mathrm{b}$ & $\mathrm{L}_{50}$ & $\mathrm{~b}$ & $\mathrm{~L}_{50}$ & $\mathrm{~b}$ & $\mathrm{~L}_{50}$ & $\mathrm{~b}$ & $\mathrm{~L}_{50}$ \\
\hline Diplodus vulgaris & 0.465 & 18.21 & 0.533 & 20.89 & 0.588 & 23.03 & 0.641 & 25.13 \\
\hline Pagellus acarne & 0.203 & 17.67 & 0.233 & 20.27 & 0.256 & 22.35 & 0.280 & 24.39 \\
\hline Pagellus erythrinus & 0.554 & 17.89 & 0.636 & 20.52 & 0.701 & 22.63 & 0.765 & 24.70 \\
\hline Spondyliosoma cantharus & 0.345 & 17.64 & 0.395 & 20.23 & 0.436 & 22.31 & 0.476 & 24.34 \\
\hline
\end{tabular}


are shown in Fig. 5 together with the uni-modal model fits for the same data and the gill net selectivity curves for the same species. As can be seen in Figure 5 and Table 9, the $\mathrm{L}_{50}$ values for the smallest hook size (number 15) ranged from 17.64 to $18.21 \mathrm{~cm}$, whereas for the largest hook size (number 11), the range for all species was from 24.34 to $25.13 \mathrm{~cm}$.

\section{DISCUSSION}

Quantification of the role that different fishing gears play in the utilisation of a resource has long been recognised to be an important basis for rational exploitation. Catch composition and size frequency distributions of different gears and gear configurations depend not only on the size selection properties of the gear but also on fishing strategies and spatio-temporal factors that influence the size structure of the fished population (Halliday, 2002). Thus, gear comparison studies must be carefully planned and executed in order to avoid confounding effects. Furthermore, if size selectivity of hooks is an objective of the study, a control gear should be used, the catches of which can be assumed to be representative of the fished population (Huse et al.,. 2000; Halliday, 2002).

A number of studies have compared different gears in terms of catch rates, efficiency and size selection. However, in most cases the studies have focused on one or two species, with few examples of a multi-species nature and, with the exception of a few studies such as those of Huse et al. (2000), Halliday (2002) and Stergiou and Erzini (2002), most did not avoid the above mentioned confounding effects. In the current study bias due to spatial variability was minimised by ensuring that fishing with the two gears took place on the same fishing grounds and at the same time. Ideally, estimation of size selectivity parameters should be based on a single set of gear or from a limited number of sets because of the possibility of between-set variation and subsequent over-dispersion due to pooling of data (Millar and Fryer, 1999; Holst, pers. com.). In this study data had to be pooled due to the relatively small numbers of each species caught with each mesh size and hook size per set of the gear. However, based on our understanding of the biology and fisheries of these sea breams (Erzini et al., 2001, 2002), we do not believe that there are significant changes in the size structure of the exploit- ed populations over the year and therefor pooling of data from many sets does not introduce signifiant bias.

Small hook longline catches have previously been compared with those of monofilament gill nets fished in different years and areas in Algarve waters by Erzini et al. (1996b), with many species in common with the present study. As in the present study, pronounced differences were found in terms of catch composition and size ranges. The present study, along with that of Stergiou and Erzini (2002) using the same gear in Cyclades waters, confirms the results of Erzini et al. (1996b), who reported that for most species caught by both gears there were clear differences in size distributions and catch composition. As reported by Erzini et al. (1996a, 1998), for the same species and the same hook sizes the longline catch frequency distributions tend to be skewed to the right with little or no difference in the minimum size caught by the different sizes of hooks, and the numbers caught tended to decrease with increasing hook size. However, while the smaller hook sizes clearly catch more smaller fish, all four hook sizes caught similar numbers of the largest individuals. The analysis of the sizes of fish caught by the two gears in the study area clearly indicated that gill nets were more size-selective than longlines, with each mesh size catching a relatively narrow size range of fish.

The four gill net mesh sizes used in this study include the most widely used legal mesh sizes in Algarve coastal waters, while the number 12 and 13 hook sizes are those most commonly used for the smaller species of sea breams. The comparison of the catch distributions of the two gears shows that gill nets generally caught smaller sizes and smaller size ranges than did longlines. This is supported by the estimated modal lengths and spreads of unimodal model SELECT fits, which were in most cases much larger for hooks than nets. Thus, longlines target the larger individuals and this has important implications for the sea breams (Sparidae) that are hermaphroditic, particularly those species in which the largest individuals are females. For example, dramatic decreases in mean size and even commercial extinction has been reported for the protandrous black spot sea bream (Pagellus bogaraveo) in the Cantabrian Sea, where it is fished almost exclusively with hook and line (E. Puente, pers. com.).

According to Millar (1995), the form of the selection curves for hooks cannot be determined 
from the catch size frequency distributions of different sizes of hooks alone. Since a variety of different selectivity models may give equally good fits, comparison of hook data with that of a control gear is necessary in order to select the appropriate model. In the present study data was available for gill nets, for which there is a general consensus on the form of selection curves (Fujimori and Tokai, 2001). Comparison of the hook catch distributions with those of gill nets clearly shows that for most species hooks catch a wider size range and that the catch ratio of hooks to gill nets per size class increases with size. Together with the results of a preliminary graphical analysis (Millar, 1995), and based on our own experience with the way these species are caught with hooks (Erzini et al., 1996a, 1997b, 1998), it was decided to fit logistic selection curves to all species caught by longlines in addition to the SELECT unimodal model fits. Halliday (2002) compared the catches of cod and haddock with three sizes of circle hooks with those of a small mesh (40 $\mathrm{mm}$ ) cod end otter trawl and also concludes that logistic model selectivity is more appropriate for circle hooks.

The bi-normal model was not fitted to the longline data since it could not be justified in terms of hooking mechanisms. For the four most important species caught with longline, the estimated $\mathrm{L}_{50}$ values of the logistic curves for the four hook sizes did not differ greatly, whereas the slopes (b) did, with much sharper selection of Diplodus vulgaris and Pagellus erythrinus. The similar $\mathrm{L}_{50}$ estimates for each hook size for the four species is to be expected given the catch size frequency distributions. In all four species and for all four hook sizes, the size at first capture varies between 15 and $20 \mathrm{~cm}$ and the peaks in the catch distributions are at lengths of between 20 and $25 \mathrm{~cm}$ for three of the species. For Pagellus erythrinus peak catches per hook size correspond to a broader size range. In all cases the estimates of $\mathrm{L}_{50}$ correspond to the ascending part of the catch length frequency distribution, which is to be expected.

For most species caught with gill nets, the bi-normal model gave the best fits, with substantial reductions in model deviance, indicating that in addition to wedging or gilling, most species were also entangled in significant numbers. Analysis of the deviance residuals showed that in general there were no obvious clustering problems and that therefore the fits were satisfactory. The modal lengths of the SELECT unimodal model fits were generally greater than expected, especially for the largest mesh sizes. This is probably due to the principal of geometric similarity (Baranov, 1914) that is assumed in all but one of the models implemented in the GILLNET software. This implies that selectivity model parameters are proportional to mesh size, and may contribute to the modal lengths being greater than the peaks of the corresponding catch size frequency distributions, especially in the case of species in which the catch distributions for the four mesh sizes are more overlapped.

Improved assessment and management of multispecies, multi-gear fisheries requires a better understanding of the relative distribution of instantaneous fishing mortality and fishing effort among the different gears in the fishery. A general fishing mortality model with a number of different components, including those associated with commercial, artisanal, and recreational landings was developed by Chopin et al. (1995, 1996). In order to obtain accurate estimates of fishing mortality for evaluating the state of the stock and the impact of fishing activities, all the above components of fishing mortality should be quantified. The results of the present study indicate that fishing mortality rates or the impact of different gears are likely to be significantly different. Direct evidence is provided by the significantly different catch size frequency distributions with the two gears as well as the different catch compositions and the size selectivity of the two gears. Since the instantaneous fishing mortality rate represents the global effect of fishing activity on a stock, the results of the present comparison of size selectivity suggested that it is important to understand the relative impact of each gear. With information on fishing effort, the results of comparative selectivity studies such as the present ones can be used to improve management by, for example, leading to a more rational and objective distribution of licences among gears.

\section{ACKNOWLEDGEMENTS}

We would like to thank José dos Santos, skipper of the "Boa Esperança", Carlos Flor, skipper of the "Silvio Manuel", and their crews for carrying out the experimental fishing trials. We are grateful for the thorough reviews of two unidentified referees. Their comments greatly improved the manuscript. Many thanks are also due to Professor José Antonio Hernando Casal for his help with translation. 


\section{REFERENCES}

Anon. - 1995. Catalogue international des activités des flotilles de la Manche, approche des interactions techniques. IFREMER.

Baranov, F.I. - 1914. The capture of fish by gillnets. Mater. Poznaniyu Russ. Rybolov., 3(6): 56-99. (Partially translated from Russian by W. E. Ricker).

Chopin, F., Y. Inoue, Y. Matsushita, and T. Arimoto. - 1995. Sources of accounted and unaccounted fishing mortality. In: B. Baxter and S. Keller (eds.), Solving bycatch,: considerations for today and tomorrow. Proceedings of the Solving Bycatch Workshop, pp. 41-47, University of Alaska Sea Grant College Program Report No. 96-03.

Chopin, F., Y. Inoue, and T. Arimoto. - 1996. Development of a catch mortality model. Fish. Res., 25: 377-382.

Clark, J.R. 1960 - Report on selectivity of fishing gear. ICNAF Spec. Publ., 2: 27-36.

CONSTAT. - 1998. GILLNET software, Denmark.

Durand, J.C., H. Farrugio and M. Lemoine. - 1991. Analyse et gestion des pêcheries cotieres. Necessité d'une nouvelle demarche. In: J.R. Durand, J. Lemoalle and J. Weber (eds.), La recherche face a la pêche artisanale - symposium international, 2: 671-680.

Elliott, J.C. and R.C. Beamesderfer. - 1990. Comparison of efficiency and selectivity of three gears used to sample white sturgeon in a Columbia River reservoir. Cal. Fish Game, 76: 174-180.

Engas, A., S. Løkkeborg, A.V. Soldal and E. Ona. - 1993. Comparative fishing for cod and haddock with commercial trawl and longline at two different stock levels. NAFO Sci. Counc. Rep. Doc., No. 117, 14 pp.

Erzini, K., J.M.S. Gonçalves, L. Bentes, P.G. Lino and J. Cruz. 1996a. Species and size selectivity in a multispecies Portuguese artisanal longline fishery. ICES J. Mar. Sci., 53: 811-819.

Erzini, K., M.N. Santos, C.C. Monteiro, J.M.S. Gonçalves, L. Bentes and P.G. Lino. - 1996b. A comparison of monofilament gillnet and small hook longline selectivity in a multispecies artisanal fishery in the Algarve (South of Portugal). NAGA (ICLARM QUARTERLY), 19: 29-32.

Erzini, K., C.C. Monteiro, J. Ribeiro, M.N. Santos, M. Gaspar, P. Monteiro and T.C. Borges. - 1997a. An experimental study of gill net and trammel net 'ghost fishing' off the Algarve (southern Portugal). Mar. Ecol. Prog. Ser., 158:257-265.

Erzini, K., J.M.S. Gonçalves, L. Bentes and P.G. Lino. - 1997b. Fish mouth dimensions and size selectivity in a Portuguese longline fishery. J. Appl. Ichthyol., 13: 41-44.

Erzini, K., J.M.S. Gonçalves, L. Bentes, P.G. Lino and J. Ribeiro. 1998. Species and size selectivity in a 'red' sea bream longline métier in the Algarve (southern Portugal). Aquat. Living Resour., 11: 1-11.

Erzini, K., L. Bentes, R. Coelho, C. Correia, P.G. Lino, P. Monteiro, J. Ribeiro and J.M.S. Gonçalves. - 2001. Fisheries biology and assessment of demersal species (Sparidae) from the south of Portugal. Commission of the European Communities DG XIV/C/1, Final Report Ref. 98/082, 263 p.

Erzini, K., L. Bentes, R. Coelho, C. Correia, P.G. Lino, P. Monteiro, J. Ribeiro and J.M.S. Gonçalves. - 2002. Recruitment of sea breams (Sparidae) and other commercially important species in the Algarve (southern Portugal). Commission of the European Communities DG XIV/C/1, Final Report Ref. 99/061, 178 pp. + appencides.

Fujimori, Y. and T. Tokai. - 2001. Estimation of gillnet selectivity curve by maximum likelihood method. Fish. Sci., 67: 644-654.

Halliday, R.G. - 2002. A comparison of size selection of Atlantic cod (Gadus morhua) and haddock (Melanogrammus aeglefinnus) by bottom longlines and otter trawls. Fish. Res. 57: 63-73.

Hareide, N.-R. - 1995. Comparisons between longlining and trawling for deep-water species - selectivity, quality and catchability - a review. In: A.G. Hopper (ed.), Deep-Water Fisheries of the North Atlantic Oceanic Slope, pp. 227-234. Kluwer Academic Publishers.
Hartman, W.M. - (no date). The NLP Procedure: Release 6.10. Extended User's Guide. SAS Institute, Inc. 325 pp.

Huse, H., A.C. Gundersen and K.H. Nedreaas. - 1999. Relative selectivity of Greenland halibut (Reinhardtius hippoglossoides, Walbaum) by trawls, longlines and gillnets. Fish. Res., 44: 75-93.

Huse, H., S. Løkkeborg and A.V. Soldal. - 2000. Relative selectivity in trawl, longline and gillnet fisheries for cod and haddock. ICES J. Mar. Sci., 57: 1271-1282.

Jørgensen, O.A. - 1995. A comparison of deepwater trawl and longline research fishing in the Davis Strait. In: A.G. Hopper (ed.), Deep-Water Fisheries of the North Atlantic Oceanic Slope, pp. 235-250. Kluwer Academic Publishers.

Kirkwood, G.P. and T.I. Walker. - 1986. Gill net selectivities for gummy shark, Mustelus antarcticus Günther, taken in southeastern Australian waters. Austr.. J. Mar. Freshw. Res., 37: 689-697.

Martins, R., M.N. Santos, C.C. Monteiro and M.C.P. Franca. 1992. Contribuição para o estudo da selectividade das redes de emalhar de um pano fundeadas na costa Portuguesa no biénio 1990-1991. Relatórios Técnicos e Científicos INIP, 62: 27pp.

Millar, R.B. - 1992. Estimating the size-selectivity of fishing gear by conditioning on the total catch. J. Amer. Stat. Assoc., 87: 962-968.

Millar, R.B. - 1995. The functional form of hook and gillnet selection curves can not be determined from comparative catch data alone. Can. J. Fish. Aquat. Sci., 52: 883-891.

Millar, R.B. and R.J. Fryer. - 1999. Estimating the size-selection curves of towed gears, traps, nets and hooks. Rev. Fish Biol. Fish., 9: 89-116.

Nedreaas, K., A.V. Soldal and A. Bjordal. - 1993. Performance and biological implications of a multi-gear fishery for Greenland halibut (Reinhardtius hippoglossoides). NAFO Sci. Counc. Rep. Doc., 118, 15pp.

Rollefsen, G. - 1953. The selectivity of different fishing gear used in Lofoten. J. Cons., 19: 191-194.

Russell, G.M., E.J. Gutherz and C.A. Barans. - 1988. Evaluation of demersal longline gear off South Carolina and Puerto Rico with emphasis on deep-water reef fish stocks. Mar. Fish. Rev., 50: 26-31.

Santos, M.N. - 1997. Ichthyofauna of the artificial reefs of the Algarve coast. Exploitation strategies and management of local fisheries. PhD Dissertaion, Universidade do Algarve, $223 \mathrm{pp}+$ annexes.

Santos, M.N. and C.C. Monteiro. - 1995. Estudo da selectividade da rede de emalhar de um pano fundeada na costa sul Algarvia. Bol. Inst. Port. Invest. Marít., Lisboa, 3: 37-48.

Santos, M., C.C. Monteiro and K. Erzini. - 1995. Aspects of the biology and gillnet selectivity of the axillary seabream (Pagellus acarne) and the common pandora (Pagellus erythrinus) from the Algarve (South Portugal). Fish. Res., 23: 223-236.

Santos, M., C.C. Monteiro, K. Erzini and G. Lasserre. - 1998. Maturation and gill-net selectivity of two small sea breams (genus Diplodus) from the Algarve coast (South Portugal). Fish. Res., 36: 185-194.

SAS Institute Inc. - 1988. SAS/STAT User's Guide, Release 6.03 Edition. Cary, NC

Siegel, S. and N.J. Castellan. - 1988. Nonparametric statistics for the behavioural sciences. Statistics Series, 2nd Edition, McGraw-Hill, New York.

Sousa, F., E. Isidro, E. and K. Erzini. - 1999. Semi-pelagic longline selectivity for two demersal species from the Azores: the black spot sea bream (Pagellus bogaraveo) and the bluemouth rock fish (Helicolenus dactylopterus dactylopterus). Fish. Res., 41: 25-35

Stergiou, K. and K. Erzini. - 2002. Comparative fixed gear studies in the Cyclades (Aegean Sea): size selectivity of small-hook longlines and monfilament gill nets. Fish. Res., 58: 25-40

Wulff, A. - 1986. Mathematical model for selectivity of gill nets. Arch. Fish Wiss., 37: 101-106.

Scient. ed.: P. Sánchez 